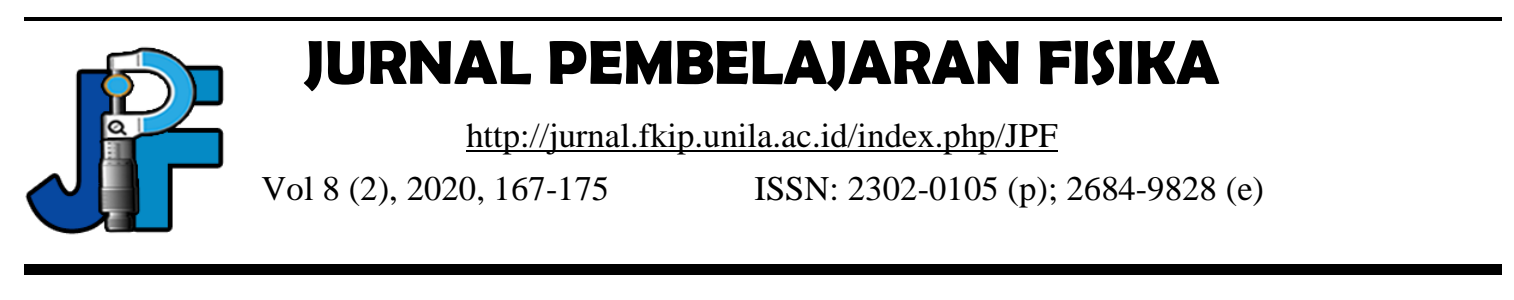

\title{
Students' Epistemic Game according to SOLO Taxonomy in Completing Fluid Mechanics Problem
}

\author{
M. Dewi Manikta Puspitasari*, Kuni Nadliroh, Muhammad Najibulloh Muzaki \\ Universitas Nusantara PGRI Kediri, Indonesia \\ *e-mail:dewimanikta@gmail.com
}

Received: November 14, 2020

Accepted: December 31, 2020

Published: December 31, 2020

\begin{abstract}
The purpose of this study is to describe the students' epistemic game of high physicscapable. This study is qualitative. The participants are students taking fluid mechanics courses. The collect data of this study use fluid mechanics test, physics understanding test and interview. The understanding test determine the students' understanding level, while the determining students' epistemic game by SOLO taxonomy use the fluid mechanics test. The students complete the first test by using mapping mathematics to meaning in a relational level and transliteration to mathematics in a multistructural level. Pictorial analysis in level extended abstract and transliteration to mathematics in level relational are used by the students in completing problem of the second test. Meanwhile, this study result showed that mapping mathematics to meaning and recursive plug and chug in a relational level are used the students for completing the third test. Furthermore, the students completing the fourth test used transliteration to mathematics and recursive plug and chug in a relational level The students' epistemic game by SOLO taxonomy of this study can be used to develop physics learning.
\end{abstract}

Keywords: epistemic game, SOLO taxonomy, fluid mechanics

DOI: http://dx.doi.org/10.23960/jpf.v8.n2.202005 


\section{INTRODUCTION}

The educational orientation has shifted preparing students to be ready to face and overcome cognitive challenges. This is due to the increasingly diverse needs of the world of work in requiring people who are able to solve problems. In facing the world of work in the future, students are not only equipped with concept understanding but also the ability to think in using their knowledge in solving problems. This also happens to the concept of fluid. The fluid learning process is still informative and lacks real experience for students. One of the results of a study shows that physics learning tends to be informative and does not facilitate students in connecting concepts learned with related phenomena (Fathiah et al., 2015). Students have the direct learning experience and affect the student's understanding.

An appropriate strategy focused on teaching fluid mechanics to further motivate students. This strategy must take into account the activeness of students in participing, where they are not only passive recipients of information. Student knowledge with a fundamental theoretical structure fails to develop the skills and practical abilities that are needed by the job market. Problem solving is an inherent part of engineering. The fluid mechanics teaching and learning process has difficult characteristics and does not attract many engineering students. Some very interesting experinces have been introduced to overcome this, such as project based learning. Educators should reflect on the potential lack of interest or participation by students in class and the difficulty understanding concepts or verbal and written expressions in their teaching methodology. It is also assumed that it is possible that the instructor's teaching strategy is incompatible with the learning styles of most students, which does not promote a positive climate of motivation and assimilation for students.

Productive learning from fluid mechanics, with activities that appeal to all learning styles. At the same time, this methodology should motivate students in highlighting important concepts, using simple examples while leaving aside outdated methods and procedures that are no longer used. In the opinion of many scientists, individual work forms in students required volume and level of knowledge, skills and abilities to complete cognitive tasks at each training step and develop mental sets into systematic knowledge and skills acquisition (Guseinova, 2018).

The effecriveness of the educational process depends on the involvement of students in active learning activities, as someone who develops and presents himself in activities. The development of practical work (PW) and several assessment moments have had a positive impact on the way they focus on content and follow the cources being taught, provide knowledge of the field under study, encourage collaborative work and stimulate students' intellectual curiosity (Sena-Esteves et al., 2019). The assessment moments help provide knowledge of the area under study, encourage collaborative work and stimulate theor intellectual curiosity, but they still have difficulty linking the acquired concepts to other chapters. The findings of Suarez's study (Suarez et al., 2017) suggest that the most critical difficulties arise from the inability of students to establishthe relationship between kinematics and fluid dynamics in motion, and from a lack of understanding of how different regions of the system interact. This ensures that understanding student misunderstandings and difficulties is a step that needs to be corrected in the field of science and engineering. Not only that, the quality of students' thinking determines the quality of what they design, produce or make in understanding the concept (Adair \& Jaeger, 2016). This thinking considers and 
articulates assumption in problem solving. The learning model also plays a role when students solve the problems. However, this is constrained if it is done online as found in Aunillah' study (Niswatun Aunillah et al., 2018), some student are late in submitting their assignments. In addition, students can easily practice solving different problem with online learning.

Epistemic game is inseparable from the students' thought process in solving problems. SOLO taxonomy is a tool used to categorize student thinking. This is based on research which showed that the thinking framework is characterized by the SOLO taxonomy (Kamol \& Har, 2010). The SOLO taxonomy framework classifies the ability of thought process of an issue. This classifies the level of response for the development of thought processes.

\section{METHOD}

This study is qualitative research (Miles \& Huberman, 1994). The students' epistemic game of high physics-capable are determined by solving fluid mechanics test and interview.

\section{Participants}

The participant of this study consisted of 73 Mechanical Engineering students, Faculty of Engineering, Universitas Nusantara PGRI Kediri. Based on students' result of physics understanding test, there were 67 out of 73 high physics-capable students.

\section{Data Collection and Instrument}

1. Test

The physics understanding test and the fluid mechanics test are used to collect the data. The physics understanding test consists of 7 questions on physics problem to determine physics-capable students. While the fluid mechanics test consisted of 4 measuring and fluid questions for determining students' epistemic game.

2. Interview

The interviews were used to complement and reinforce the findings of this study. The result of fluid mechanics test was used to interview the students.

\section{Data Analysis}

The analysis of this study was carried out in three stages as follows:

1. The data reduction

The process of selecting epistemic game data according to SOLO taxonomy based on the level of relevance and its relationship with each data of epistemic game in data reduction. Other than that, it is also focused on data entry and simplification of raw epistemic game data according to SOLO taxonomy in the field in the form of game data. Extracted and transformed data obtained into general epistemic game data according to SOLO taxonomy. Activity of data reduction begin with reading, studying and understanding all the data obtained.

2. The data presentation

The data presentation consists of activities grouping by ability grouping criteria physics students and the identification data is done by writing the data collection on the 
regular basic and categorized so that it can be deduced. The data presentation activity aims to make conclusions easily.

3. The conclusion

The conclusion was to provide an explanation of the meaning and results of presenting the data. Futhermore, conclusion was shown to formulate the students' fluid mechanics problem solving strategies. Conslusions obtained based on data presentation.

\section{RESULT AND DISCUSSION}

High physics-capable students include 67 students. Epistemic game SOLO taxonomy according to the distribution of high physics-capable students in solving fluid mechanics are presented in Table 1.

Table 1. Epistemic Game by SOLO Taxonomy Distribution of High Physics-Capable Students in Solving Fluid Mechanics

\begin{tabular}{|c|c|c|c|c|c|c|c|c|c|}
\hline \multirow[t]{2}{*}{ No. } & \multirow[t]{2}{*}{ Kode } & \multicolumn{4}{|c|}{ Epistemic Game } & \multicolumn{4}{|c|}{ Level Taksonomi Solo } \\
\hline & & 1 & 2 & 3 & 4 & 1 & 2 & 3 & 4 \\
\hline 1 & M001 & MMM2 & TM & RPC & RPC & $\mathrm{R}$ & $\mathrm{R}$ & $\mathrm{R}$ & $\mathrm{R}$ \\
\hline 2 & M002 & MMM2 & TM & RPC & RPC & $\mathrm{R}$ & $\mathrm{R}$ & $\mathrm{R}$ & $\mathrm{R}$ \\
\hline 3 & M005 & $\mathrm{TM}$ & TM & RPC & RPC & $\mathrm{M}$ & $\mathrm{R}$ & $\mathrm{R}$ & $\mathrm{R}$ \\
\hline 4 & M006 & $\mathrm{TM}$ & TM & MMM2 & RPC & $\mathrm{M}$ & $\mathrm{R}$ & $\mathrm{R}$ & $\mathrm{R}$ \\
\hline 5 & M007 & MMM2 & TM & $\mathrm{RPC}$ & RPC & $\mathrm{R}$ & $\mathrm{R}$ & $\mathrm{R}$ & $\mathrm{R}$ \\
\hline 6 & M008 & MMM2 & TM & RPC & $\mathrm{RPC}$ & $\mathrm{R}$ & $\mathrm{R}$ & $\mathrm{R}$ & $\mathrm{R}$ \\
\hline 7 & M010 & MMM2 & $\mathrm{TM}$ & RPC & $\mathrm{RPC}$ & $\mathrm{R}$ & $\mathrm{R}$ & $\mathrm{R}$ & $\mathrm{R}$ \\
\hline 8 & M011 & MMM2 & PA & RPC & $\mathrm{RPC}$ & $\mathrm{R}$ & EA & $\mathrm{R}$ & $\mathrm{R}$ \\
\hline 9 & M016 & MMM2 & TM & RPC & $\mathrm{RPC}$ & $\mathrm{R}$ & $\mathrm{R}$ & $\mathrm{R}$ & $\mathrm{R}$ \\
\hline 10 & M018 & MMM2 & $\mathrm{TM}$ & RPC & RPC & $\mathrm{R}$ & $\mathrm{R}$ & $\mathrm{R}$ & $\mathrm{R}$ \\
\hline 11 & M019 & $\mathrm{TM}$ & $\mathrm{TM}$ & RPC & RPC & $\mathrm{M}$ & $\mathrm{R}$ & $\mathrm{R}$ & $\mathrm{R}$ \\
\hline 12 & M020 & MMM2 & $\mathrm{TM}$ & RPC & RPC & $\mathrm{R}$ & $\mathrm{R}$ & $\mathrm{R}$ & $\mathrm{R}$ \\
\hline 13 & M021 & MMM2 & $\mathrm{TM}$ & RPC & RPC & $\mathrm{R}$ & $\mathrm{R}$ & $\mathrm{R}$ & $\mathrm{R}$ \\
\hline 14 & M022 & MMM2 & $\mathrm{TM}$ & RPC & RPC & $\mathrm{R}$ & $\mathrm{R}$ & $\mathrm{R}$ & $\mathrm{R}$ \\
\hline 15 & M028 & $\mathrm{TM}$ & $\mathrm{TM}$ & RPC & RPC & M & $\mathrm{R}$ & $\mathrm{R}$ & $\mathrm{R}$ \\
\hline 16 & M029 & MMM2 & TM & RPC & RPC & $\mathrm{R}$ & $\mathrm{R}$ & $\mathrm{R}$ & $\mathrm{R}$ \\
\hline 17 & M030 & TM & $\mathrm{TM}$ & RPC & RPC & $\mathrm{M}$ & $\mathrm{R}$ & $\mathrm{R}$ & $\mathrm{R}$ \\
\hline 18 & M031 & $\mathrm{TM}$ & TM & RPC & RPC & M & $\mathrm{R}$ & $\mathrm{R}$ & $\mathrm{R}$ \\
\hline 19 & M032 & MMM2 & TM & RPC & RPC & $\mathrm{R}$ & $\mathrm{R}$ & $\mathrm{R}$ & $\mathrm{R}$ \\
\hline 20 & M034 & MMM2 & TM & RPC & RPC & $\mathrm{R}$ & $\mathrm{R}$ & $\mathrm{R}$ & $\mathrm{R}$ \\
\hline 21 & M035 & MMM2 & TM & RPC & RPC & $\mathrm{R}$ & $\mathrm{R}$ & $\mathrm{R}$ & $\mathrm{R}$ \\
\hline 22 & M036 & $\mathrm{TM}$ & TM & RPC & RPC & M & $\mathrm{R}$ & $\mathrm{R}$ & $\mathrm{R}$ \\
\hline 23 & M037 & MMM2 & PA & RPC & RPC & $\mathrm{R}$ & EA & $\mathrm{R}$ & $\mathrm{R}$ \\
\hline 24 & M038 & MMM2 & PA & RPC & RPC & $\mathrm{R}$ & EA & $\mathrm{R}$ & $\mathrm{R}$ \\
\hline 25 & M039 & MMM2 & TM & RPC & RPC & $\mathrm{R}$ & $\mathrm{R}$ & $\mathrm{R}$ & $\mathrm{R}$ \\
\hline 26 & M040 & MMM2 & PA & RPC & RPC & $\mathrm{R}$ & EA & $\mathrm{R}$ & $\mathrm{R}$ \\
\hline 27 & M042 & MMM2 & TM & RPC & RPC & $\mathrm{R}$ & $\mathrm{R}$ & $\mathrm{R}$ & $\mathrm{R}$ \\
\hline 28 & M043 & MMM2 & PA & RPC & RPC & $\mathrm{R}$ & EA & $\mathrm{R}$ & $\mathrm{R}$ \\
\hline 29 & M044 & MMM2 & $\mathrm{TM}$ & RPC & RPC & $\mathrm{R}$ & $\mathrm{R}$ & $\mathrm{R}$ & $\mathrm{R}$ \\
\hline 30 & M047 & MMM2 & PA & RPC & RPC & $\mathrm{R}$ & EA & $\mathrm{R}$ & $\mathrm{R}$ \\
\hline 31 & M050 & MMM2 & PA & RPC & RPC & $\mathrm{R}$ & EA & $\mathrm{R}$ & $\mathrm{R}$ \\
\hline 32 & M053 & $\mathrm{TM}$ & TM & RPC & RPC & $\mathrm{M}$ & $\mathrm{R}$ & $\mathrm{R}$ & $\mathrm{R}$ \\
\hline 33 & M054 & TM & TM & MMM2 & RPC & $\mathrm{M}$ & $\mathrm{R}$ & $\mathrm{R}$ & $\mathrm{R}$ \\
\hline
\end{tabular}




\begin{tabular}{|c|c|c|c|c|c|c|c|c|c|}
\hline 34 & M055 & MMM2 & TM & RPC & RPC & $\mathrm{R}$ & $\mathrm{R}$ & $\mathrm{R}$ & $\mathrm{R}$ \\
\hline 35 & M056 & TM & $\mathrm{TM}$ & RPC & RPC & M & $\mathrm{R}$ & $\mathrm{R}$ & $\mathrm{R}$ \\
\hline 36 & M058 & MMM2 & $\mathrm{TM}$ & RPC & RPC & $\mathrm{R}$ & $\mathrm{R}$ & $\mathrm{R}$ & $\mathrm{R}$ \\
\hline 37 & M059 & MMM2 & $\mathrm{TM}$ & RPC & TM & $\mathrm{R}$ & $\mathrm{R}$ & $\mathrm{R}$ & $\mathrm{R}$ \\
\hline 38 & M060 & TM & $\mathrm{TM}$ & RPC & RPC & M & $\mathrm{R}$ & $\mathrm{R}$ & $\mathrm{R}$ \\
\hline 39 & M062 & MMM2 & $\mathrm{TM}$ & RPC & RPC & $\mathrm{R}$ & $\mathrm{R}$ & $\mathrm{R}$ & $\mathrm{R}$ \\
\hline 40 & M063 & MMM2 & PA & RPC & RPC & $\mathrm{R}$ & EA & $\mathrm{R}$ & $\mathrm{R}$ \\
\hline 41 & M064 & MMM2 & $\mathrm{TM}$ & RPC & RPC & $\mathrm{R}$ & $\mathrm{R}$ & $\mathrm{R}$ & $\mathrm{R}$ \\
\hline 42 & M070 & MMM2 & $\mathrm{TM}$ & RPC & RPC & $\mathrm{R}$ & $\mathrm{R}$ & $\mathrm{R}$ & $\mathrm{R}$ \\
\hline 43 & M071 & MMM2 & PA & RPC & RPC & $\mathrm{R}$ & EA & $\mathrm{R}$ & $\mathrm{R}$ \\
\hline 44 & M072 & MMM2 & PA & RPC & RPC & $\mathrm{R}$ & EA & $\mathrm{R}$ & $\mathrm{R}$ \\
\hline 45 & M073 & MMM2 & $\mathrm{TM}$ & RPC & RPC & $\mathrm{R}$ & $\mathrm{R}$ & $\mathrm{R}$ & $\mathrm{R}$ \\
\hline 46 & M076 & MMM2 & PA & RPC & RPC & $\mathrm{R}$ & EA & $\mathrm{R}$ & $\mathrm{R}$ \\
\hline 47 & M077 & MMM2 & PA & RPC & RPC & $\mathrm{R}$ & EA & $\mathrm{R}$ & $\mathrm{R}$ \\
\hline 48 & M078 & MMM2 & PA & RPC & RPC & $\mathrm{R}$ & EA & $\mathrm{R}$ & $\mathrm{R}$ \\
\hline 49 & M080 & TM & $\mathrm{TM}$ & RPC & RPC & M & $\mathrm{R}$ & $\mathrm{R}$ & $\mathrm{R}$ \\
\hline 50 & M081 & TM & $\mathrm{TM}$ & MMM2 & RPC & M & $\mathrm{R}$ & $\mathrm{R}$ & $\mathrm{R}$ \\
\hline 51 & M082 & MMM2 & $\mathrm{TM}$ & RPC & RPC & $\mathrm{R}$ & $\mathrm{R}$ & $\mathrm{R}$ & $\mathrm{R}$ \\
\hline 52 & M083 & MMM2 & PA & RPC & RPC & $\mathrm{R}$ & EA & $\mathrm{R}$ & $\mathrm{R}$ \\
\hline 53 & M084 & MMM2 & $\mathrm{TM}$ & RPC & RPC & $\mathrm{R}$ & $\mathrm{R}$ & $\mathrm{R}$ & $\mathrm{R}$ \\
\hline 54 & M085 & MMM2 & PA & RPC & RPC & $\mathrm{R}$ & EA & $\mathrm{R}$ & $\mathrm{R}$ \\
\hline 55 & M087 & MMM2 & $\mathrm{TM}$ & RPC & RPC & $\mathrm{R}$ & $\mathrm{R}$ & $\mathrm{R}$ & $\mathrm{R}$ \\
\hline 56 & M089 & MMM2 & $\mathrm{TM}$ & RPC & TM & $\mathrm{R}$ & $\mathrm{R}$ & $\mathrm{R}$ & $\mathrm{R}$ \\
\hline 57 & M091 & MMM2 & $\mathrm{TM}$ & RPC & RPC & $\mathrm{R}$ & $\mathrm{R}$ & $\mathrm{R}$ & $\mathrm{R}$ \\
\hline 58 & M092 & MMM2 & $\mathrm{TM}$ & RPC & RPC & $\mathrm{R}$ & $\mathrm{R}$ & $\mathrm{R}$ & $\mathrm{R}$ \\
\hline 59 & M093 & MMM2 & PA & RPC & RPC & $\mathrm{R}$ & EA & $\mathrm{R}$ & $\mathrm{R}$ \\
\hline 60 & M095 & $\mathrm{TM}$ & $\mathrm{TM}$ & RPC & RPC & M & $\mathrm{R}$ & $\mathrm{R}$ & $\mathrm{R}$ \\
\hline 61 & M097 & MMM2 & $\mathrm{TM}$ & RPC & TM & $\mathrm{R}$ & $\mathrm{R}$ & $\mathrm{R}$ & $\mathrm{R}$ \\
\hline 62 & M99 & MMM2 & PA & RPC & RPC & $\mathrm{R}$ & EA & $\mathrm{R}$ & $\mathrm{R}$ \\
\hline 63 & M100 & MMM2 & $\mathrm{TM}$ & RPC & RPC & $\mathrm{R}$ & $\mathrm{R}$ & $\mathrm{R}$ & $\mathrm{R}$ \\
\hline 64 & M101 & MMM2 & $\mathrm{TM}$ & RPC & RPC & $\mathrm{R}$ & $\mathrm{R}$ & $\mathrm{R}$ & $\mathrm{R}$ \\
\hline 65 & M102 & MMM2 & $\mathrm{TM}$ & RPC & RPC & $\mathrm{R}$ & $\mathrm{R}$ & $\mathrm{R}$ & $\mathrm{R}$ \\
\hline 66 & M107 & MMM2 & $\mathrm{TM}$ & RPC & RPC & $\mathrm{R}$ & $\mathrm{R}$ & $\mathrm{R}$ & $\mathrm{R}$ \\
\hline 67 & M112 & MMM2 & $\mathrm{TM}$ & RPC & RPC & $\mathrm{R}$ & $\mathrm{R}$ & $\mathrm{R}$ & $\mathrm{R}$ \\
\hline
\end{tabular}

Table 1 showed that students' epistemic game by SOLO taxonomy distribution of high physics-capable to complete fluid mechanics test. M087 was code of students whereas numeral showed that the student' characteristic. Meantime, epistemic game of high physics-capable students were mapping mathematics to meaning (MMM2), transliteration to mathematics (TM), recursive plug and chug (RPC) and pictorial analysis (PA). And SOLO taxonomy level of student of this study showed that students used relational (R), multistructural (M) and extended abstract (EA) in completing fluid mechanics problems.

Epistemic games are used by students with high physics capablility according to SOLO taxonomy in solving fluid mechanics problems and are described as follows: in the first test, students use mathematics to meaning mapping in a relational level and transliteration to mathematics in a multistructural level. Mapping mathematics to meaning in a relational level is used by students in identifying and combining fluid 
concepts, finding equations in solving problems and evaluating fluid problems. In this case, students use and combine all the concepts and data contained in the first test. Meanwhile, students who use transliteration to mathematics in a multistructural level identify the quantities, find the solution pattern of the first test, map the quantities and evaluate the mapping of the first test problem. This shows that students use and respond to some data and cannot connect the concepts or data contained in the first test.

The cognitive process is used by students in completing the fluid mechanics problem. Students' information understanding and providing in completing the problems is very dependent on educational goals to articulate the selection and design of problem (Teodorescu et al., 2013). They identify and combine fluid concepts, finding equations in solving problems and evaluating fluid problems. They develop the conceptual stories to be realted to physics equations in mapping mathematics to meaning (Tuminaro \& Redish, 2007). They use and respond to some data and cannot connect the concepts or data contained in the first test (Lian \& Yew, 2012).

Pictorial analysis in an extended abstract level and transliteration to mathematics in a relational level are used students to solve the second test. Pictorial analysis in an extended abstract level is used by students in determining concepts, describing the processes that occur in the flow of a tangka, explaining the problem conceptually and representing the problem. This shows that students apply equations related to problems, find general principles from data and apply them in solving problems, and provide responses by connecting the concepts or data contained in the second test. Meanwhile, students use transliteration to mathematics in a relational level to identify quantities, find the second test solution pattern, map the quantities and evaluate the mapping of the second fluid mechanics problem test. This shows that students use and combine all the concepts and data contained in the second test.

Analyzing qualitatively analysis and design used organized understanding possible solution for monitoring the students' capablility progress (Ogilvie, 2009). It showed that transliteration to mathematics use worksheet to generate solution without developing fluid mechanics understanding. The students identify quantities, find the second test solution pattern, map the quantities and evaluate the mapping of the second fluid mechanics problem test (Tuminaro \& Redish, 2007). They used a relational level too based on their response. The information aspect provided to one another are integrated into a coherent stucture (Jamil, 2017). They can connect between a fact and principles or theories in completing problems given at a hort time (Appulembang, 2017).

Epistemic games according to the SOLO taxonomy used by students in the third test include recursive plug and chug in a relational level and mapping mathematics to meaning in a relational level. Mapping mathematics to meaning was used students in a relational level in identifying and combining fluid concepts, finding equations in solving problems and evaluating fluid problems. In this case students use and combine all the concepts and data contained in the third test. Meanwhile, students who use recursive plug and chug in a relational level identify and calculate quantities, find equations related to problems, identify and determine new quantities in solving fluid mechanics problems. It shows using and combining all concepts and data.

The findings explained that students use several games to complete the fluid mechanics problem. Consistency suggests that certain resources and games are not only 
way students use or play (Tuminaro \& Redish, 2007). Epistemic game increases the students' physics understanding based on this study (Tuminaro \& Redish, 2007).

Recursive plug and chug and transliteration to mathematics have used by students to solve the fourth test in a relational level. Recursive plug and chug in a relational level is used by students in identifying and calculating quantities, finding equations related to problems, identifying and determining new quantities in solving fluid mechanics problems. In this case, students use and combine all concepts and data. Meanwhile, transliteration to mathematics in a relational level used by students to identify quantities, find the first solution pattern test, map the quantities and evaluate the mapping of fluid mechanics test problems. This shows that students use and combine all concepts and data in the fourth test.

Students use recursive plug and chug to identify and calculate quantities, find equations related to problems, identify and determine new quantities in solving fluid mechanics problems.this epistemic game is identical to mapping meaning to mathematics (Tuminaro \& Redish, 2007). It relies on understanding the physics symbols syntax without understanding the concept symbols. Students can easily solve the physics problem if it is to understand the concept with a variety representations (Khoirurrohmah et al., 2018). It shows the students' efforts involved in problem solving tasks.

\section{CONCLUSION}

This study result showed that students use used mathematics to meaning mapping in a relational level and transliteration to mathematics in a multistructural level in completing the first test. Pictorial analysis in an extended abstract level and transliteration to mathematics in a relational level are used students to complete the second test. Epistemic games according to the SOLO taxonomy used by students in the third test in a relational level include recursive plug and chug and mapping mathematics to meaning. Meantime, the fourth test that has been completed by the students in a relational level use transliteration to mathematics and recursive plug and chug.

The study focus was students' epistemic game of high physics-capable in completing the problem of fluid mechanics. Epistemic game of this study can be used as a reference in determining the appropriate fluid mechanics learning. Not only that, this epistemic game can be used as material for consideration in developing worksheets, modules, and fluid mechanics teaching materials.

\section{ACKNOWLEDGEMENTS (OPTIONAL)}

The researcher thanks to Ministry of Research, Technology and Higher Education of the Republic of Indonesia for funding this study.

\section{REFERENCES}

Adair, D., \& Jaeger, M. (2016). Incorporating Critical Thinking into an Engineering Undergraduate Learning Environment. International Journal of Higher Education, 5(2), 23-39. https://doi.org/10.5430/ijhe.v5n2p23 
Appulembang, O. D. (2017). Profil Pemecahan Masalah Aljabar Berpandu pada Taksonomi Solo Ditinjau dari Gaya Kognitif Konseptual Tempo Siswa SMA Negeri 1 Makale Tana Toraja. Journal of Language, Literature, Culture, and Education, $13(2)$,

133-149. https://ojs.uph.edu/index.php/PJI/article/download/336/pdf

Fathiah, F., Kaniawati, I., \& Utari, S. (2015). Analisis Didaktik Pembelajaran yang Dapat Meningkatkan Korelasi antara Pemahaman Konsep dan Kemampuan Pemecahan Masalah Siswa SMA pada Materi Fluida Dinamis. Jurnal Penelitian \& Pengembangan Pendidikan Fisika, 1(1), 111-118. https://doi.org/10.21009/1.01116

Guseinova, E. E. (2018). Organizational and pedagogical conditions for the development of professional competencies in the technical students' individual work through the example of studying the discipline «Hydraulics and fluid mechanics». European Journal of Contemporary Education, 7(1), 118-126. https://doi.org/10.13187/ejced.2018.1.118

Jamil, A. F. (2017). Peningkatan Level Berpikir Aljabar Siswa Berdasarkan Taksonomi SOLO pada Materi Persamaan Linier melalui Pemberian Scaffolding. Jurnal Ilmiah Mandala Education, 3(1), 175-183. http://ejournal.mandalanursa.org/index.php/JIME/article/view/34

Kamol, N., \& Har, Y. B. (2010). Upper Primary School Students' Algebraic Thinking. Proceedings of the 33rd Annual Conference of the Mathematics Education Research Group of Australasia, July, 3-7. https://files.eric.ed.gov/fulltext/ED520911.pdf

Khoirurrohmah, S., Ertikanto, C., \& Suyatna, A. (2018). Pengaruh Penggunaan Modul Pembelajaran Kontekstual berbasis Multiple Representations pada Materi Fluida Statis terhadap Hasil Belajar Siswa. Jurnal Pembelajaran Fisika, 6(1), 35-46. http://jurnal.fkip.unila.ac.id/index.php/JPF/article/view/15336

Lian, L. H., \& Yew, W. T. (2012). Assessing algebraic solving ability: A theoretical framework. International Education Studies, 5(6), 177-188. https://doi.org/10.5539/ies.v5n6p177

Miles, M. B., \& Huberman, A. M. (1994). Qualitative Data Analysis. In R. Holland (Ed.), SAGE Publications (Second). SAGE Publications.

Niswatun Aunillah, T., Suana, W., \& Distrik Wayan, I. (2018). Dampak Blended Learning pada Materi Fluida Dinamis terhadap Hasil Belajar Siswa. Jurnal Pembelajaran Fisika, 6(1), 116-121. https://doi.org/10.23960/jpf.v6.n1.201811

Ogilvie, C. A. (2009). Changes in students' problem-solving strategies in a course that includes context-rich, multifaceted problems. Physical Review Special Topics Physics Education Research, 5(2), 1-14. https://doi.org/10.1103/PhysRevSTPER.5.020102

Sena-Esteves, T., Morais, C., Guedes, A., Pereira, I. B., Ribeiro, M. M., Soares, F., \& Leão, C. P. (2019). Student's perceptions regarding assessment changes in a 
fluid mechanics course. Education Sciences, 9(2), 1-19. https://doi.org/10.3390/educsci9020152

Suarez, A., Kahan, S., Zavala, G., \& Marti, A. C. (2017). Students' conceptual difficulties in hydrodynamics. Physical Review Physics Education Research, 13(2), 1-12. https://doi.org/10.1103/PhysRevPhysEducRes.13.020132

Teodorescu, R. E., Bennhold, C., Feldman, G., \& Medsker, L. (2013). New approach to analyzing physics problems: A taxonomy of introductory physics problems. Physical Review Special Topics - Physics Education Research, 9(1), 1-20. https://doi.org/10.1103/PhysRevSTPER.9.010103

Tuminaro, J., \& Redish, E. F. (2007). Elements of a cognitive model of physics problem solving: Epistemic games. Physical Review Special Topics - Physics Education Research, 3(2), 1-22. https://doi.org/10.1103/PhysRevSTPER.3.020101 